\title{
重力式擢壁に作用する振動土压と力のつり合いについて \\ RESEARCHES ON OSCILLATING EARTH PRESSURES AND EQUILIBRIUM OF FORCES ACTING ON A GRAVITY WALL
}

\section{1. まえがき}

著者らが人工地震発生装置をつくって, 重力式擁壁に 作用する地震時土圧の研究を始めてからはや 18 年の歳 月が流れた。昭和 28 年に始まるこの研究は, 昭和 37 年 までを第 1 期とし, それ以後を第 2 期にわけることがで きる。この中で第 1 期の研究内容についてはすでに報告 $\left(\star^{1) \sim 8)}\right.$ 。第 2 期の実験は昭和 38 年 8 月から同 40 年 12 月までの間に行なわれ, その後実験結果の解析を行なっ た。本報告書は, すべて第 2 期の研究に属するものであ る。

本研究の最終目標は, 地震時に重力式擁壁に作用する 土圧と壁体の運動との関係を, 力学モデルで表現するこ とである。本報告書では, まず測定した運動と分布土圧 を直観的に把握しうる形で表現し, これから力の分布形 状を実験式で表わしてこれを積分し, 壁体に作用する合 力と合モーメントを求めた。次にこのようにして求めた 合力と合モーメントがどのようにして運動方程式を満足 するかを考察した。実測によってえられた土圧と壁体の 変位が運動方程式を満足するという事実は, 実測值を用 いて土圧の力学モデルを考察することを可能ならしめ た。土圧の力学モデルについては, 二, 三のものについ て試算を行なってみたが，満足すべき結果がえられず今 後に残された問題となった。

\section{2. 実験装置}

Fig. 1 に人工地震発生装置および試験壁体の配置を 示す。人工地震発生装置によって地盤に定常振動を起こ した場合, あるいは試験壁体の頂部に取り付けた壁頂起 振機によって壁体自身を振動源とした場合に, 試験壁体 の背後および底面に作用する土圧と壁体の運動を観測し

\footnotetext{
* 正会員 工博 運輸省船舶技術研究所 海洋開発工学部
}

$\begin{array}{llr}\text { 丹 } & \text { 羽 } & \text { 新* } \\ \text { By } & \text { Shin } & \text { Niwa }\end{array}$

た。これらの装置や, 振動および振動土圧測定装置につ いての詳細はすでに報告したもの ${ }^{1) ~ 8) ~}$ ここでは第 1 期の実験と異なる点について述べることと する。

Fig. 1 に示したように, 人工地震発生装置から 10.6 $\mathrm{m}$ 離れた地盤中に, 長さ $5 \mathrm{~m}$, 高さ $3 \mathrm{~m}$, 底幅 $1.5 \mathrm{~m}$ の試験壁体をつくり，この鉛直壁面に Goldbeck 型振動 土圧計 9 個 (No. 13, 14, 15, 16, 17, 18, 1, 2, 3), 底 面に 3 個 (No. 4, 5,6) を取り付け，振動前後および振 動中の土圧を測定した。Fig. 2 に試験壁体の標準断面 と, 裏込め側から見た鉛直壁面上の土圧計の位置を示 す。第 1 期の実験では裏込め側の $2 \mathrm{~m}$ より深い部分は, 割り栗石および原地盤となっていたが，第 2 期の実験で はこの部分を壁底まで掘り取り, 新たに No. 1, 2, 3 の 3 個の土圧計を壁面から突出して取り付けた。

試験壁体の裹込めは多摩川砂で, その有効径は 0.26 $\mathrm{mm}$, 均等係数は 4.35 である。この砂を注水しながら十 分踏み固めて埋めもどし, その後約 1 力月間放置してか ら振動実験を開始した。裏込めのある実験は約 21 力月 続き,この間裏込めの入れ替えは行なわなかった。最後

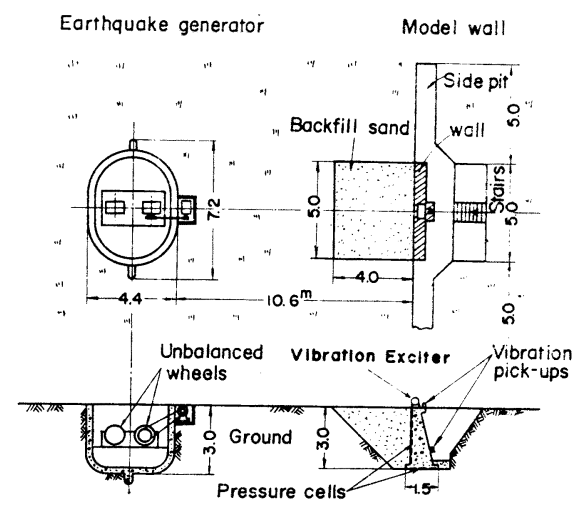

Fig. 1 General arrangement of the experimental equipments 

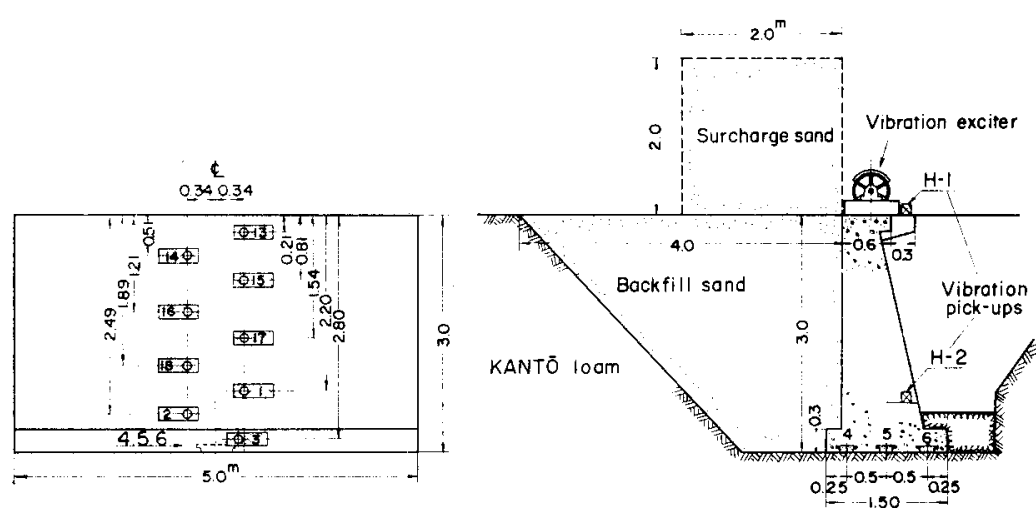

Fig. 2 Details of the model wall and the arrangement of pressure cells

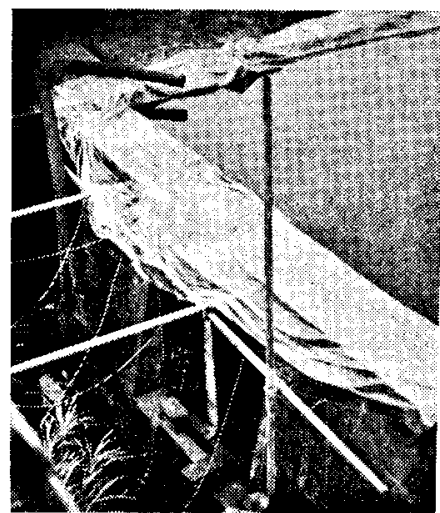

Photo 2 Filled with water instead of backfill sand

に裹込めを掘り取った際, 寒込加の各部 15 力䄬からサ行なった。

ンプルを採り土質試験を行なった。その結果，湿潤单位 体積重量 $1.69 \mathrm{~g} / \mathrm{cm}^{3}$, 含水比 $6.94 \%$, 内部摩摖角 $29^{\circ}$ であった。なおこの砂の真比重は 2.69 であり，突固め 試験の結果, 最適含水比 $12.5 \%$, 最大乾燥密度は 1.89 $\mathrm{g} / \mathrm{cm}^{3}$ である。

\section{3. 実験とその結果}

\section{（1）実験の方法}

人工地震発生装置あるいは壁頂起振機を種々の回転数 で定常回転させ，そのとき壁体の背面に取り付けた土圧 計および底面の土圧計によって振動前，振動中，振動後 の土王を測り，同時に壁体の振動を 2 個の振動計， $\mathrm{H}-1$ と H-2 で測定した (Fig. 2 参照)。底面の土圧計 No. 5 は設置後まもなく（昭和 30 年頃）故障し，No. 4 も完 全な記録を示さない。したがって底面の記録で解析に耐 えるのは Toe 側の No. 61 点だけである。

ここで人工地震発生装置で加振した実験をＩ群とし,

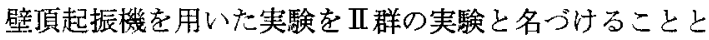
する。裹込好側の状態は次の 6 つの場合について実験を

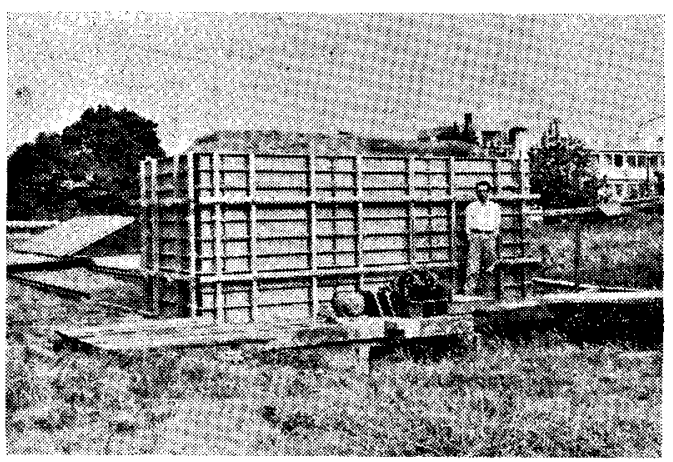

Photo 1 Surcharge, mass of sand $5 \mathrm{~m} \times 2 \mathrm{~m} \times 2 \mathrm{~m}$ in a steel frame
1. 載荷重を加える前の裏込めのみの場合

2.Fig. 2 の右図の上5に，壁体に接して全長 $5 \mathrm{~m}$, 高さ $2 \mathrm{~m}$, 幅 $2 \mathrm{~m}$ の鋼製フレームの中に砂を満たして, 寡込め上に載荷重を加えた場合。Photo 1 にその状態 を示す。

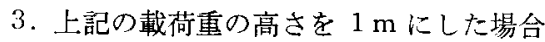

4. 載荷重を取り除いた場合

5. 裹込めの砂を㗇り取って, 代りに水を満たした場 合。Photo 2 にそのときの状態を示す。

6. 震込めがからの場合

Table 1 にこれらの組み台わせを示す。以下では，こ の表に示された番号によって実験番号を表わすこととす る。たとえば I-2-5.44は, 人工地震発生装置によって 加振し，裹込め上に高さ $2 \mathrm{~m}$ の載荷重を加えた場合の 実験で，そのときの加振振動数が $5.44 \mathrm{~Hz}$ であること 定示す。

\section{（2）実験結果の一例}

Photo 3 に I -2-5.40 の実験記録を示す。上 2 枚の オシログラムは，振動計 $\mathrm{H}-1, \mathrm{H}-2$ の変位および加速 度記録で，下の9枚は Facsimile paper に記録された 振動中の土圧である。

この記録で，壁体背後に作用する振動土土記録の波形 の位相を無視し, 振動中の土圧の最大值と最小值を, 深

Table 1 Classification of experiments

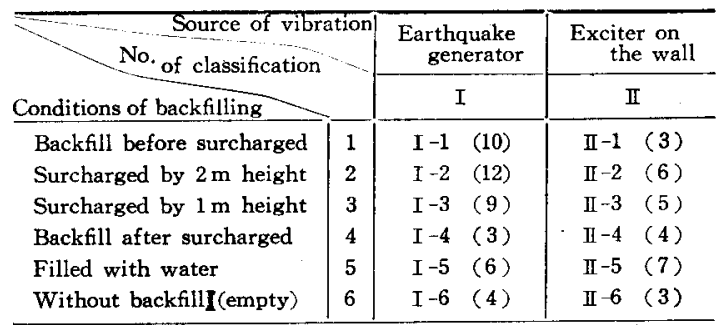

Numbers in brackets show kinds of frequency 
I-2-5.40

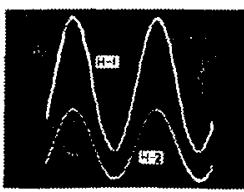

Displacement

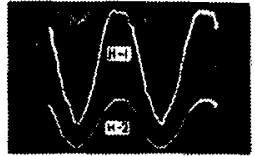

Acceleration
3
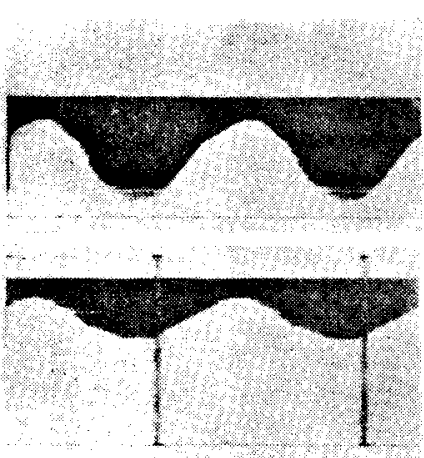

15

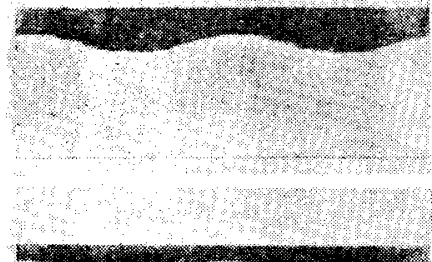

16

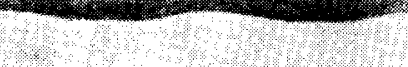

17

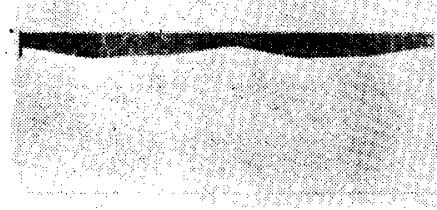

18

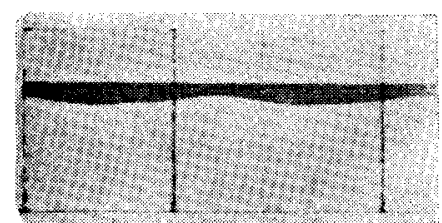

2

3
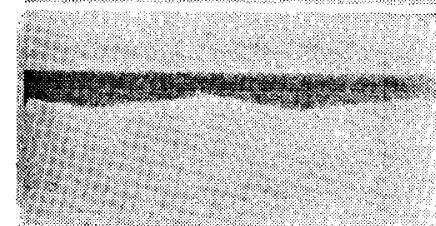

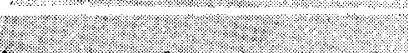

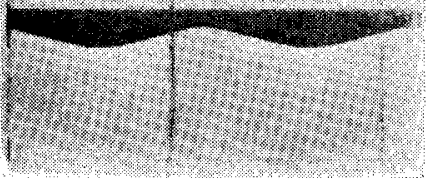

6

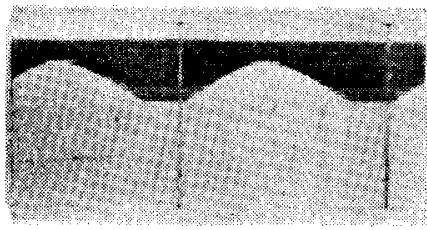

Photo 3 Oscillograms of vibration and records of oscillating earth pressure

$\left.\mathrm{cm}^{2}\right)$, 位相角 $r(\mathrm{deg})$ を 求めてこれを深さに対して プロットすれば Fig. 3 の (2) おょび (3) となる。さ らに $p \sin \gamma$ および $p \cos$ $\gamma$ を染さに対してプロット したものが, (4) および (5) である。図中○印は実測值 であり, 実線は 4.3 で述べ るようにこれらの值を実験 式化した結果である。(4)お よび (5) については改めて 次節で述べる。なお Fig. 3 の右屃に側方および底面 (土圧計 No. 6) 土圧の $p$ とて，および壁体の上下 2 力所 $(z=0$ と $z=2.16 \mathrm{~m})$ で測定した変位の基本波振 幅 $D_{1}, D_{2}$, その位相角 $\lambda_{1} ， \lambda_{2}$ を表示した。他の一 例として裹込めの砂の代り に水を満たし，壁頂起振機 を加振源としたときの動水 圧の実験結果を Fig. 4 亿 示す。

最後に, 波形分析の結果 についてひとこと触れてお こう。Photo 3 加明ら 加なように変位波形, 土圧 波形ともに, 一見して正弦 波形からのずれがあまり大 きくないことがわかる。事 実, 波形分析を行なっても 大半のものは基本波が卓越 さzに対してプロットしたものが, Fig. 3 (1) 中の陰影 を施した部分で, 振動中の土圧の変化量の絶対值を表わ している。さらに，この図の中には振動前の土圧(実 線）抒上び振動後の土圧（破線）も同時にプロットして ある。

本報告書では座標は右手系とし， $z$ 軸を鉛直下向きに とることとする。また定常振動現象を $a \cos (\omega t+\infty)$ の 形で表現し，位相角は“度”で表わすことに決めてお く。位相角の負值は“遅れ”を意味し, 位相角一振動 数曲線を書くときは, 遅れ角を綎軸の上向きにとること にする。

さて次に記録紙上にえがかれた振動土圧波形の 1 周期 を12 分割して波形分析を行ない, 基本波の振幅 $p(\mathrm{~g})$
している。2 次または 3 次調波の振幅が, 基本波の振幅 の $20 \%$ を超えるものは全体の䄪 $1 / 5$ 程度である。

\section{（3）回転ベクトルを用いた実験結果の表示法一一立 体表示法}

記録された一つの振動士圧波形は，i）振幅，ii）位 相，iii）時間，iv）測定された位置，の4つの情報を持 っている。この 4 つを1枚の紙の上に同時にアナログ量 で表現するのは不可能であり, 波形分析を行なって基本 波振動のみを問題としているいま，いちいち正弦波形を 書いて上記の i)，ii），iii）を表わすのは大して意味がな く，また直観的に把握しにくい。壁体のどの部分に，ぞ れだけの振幅の力が，どんな位相で，時間的に全体がぞ 


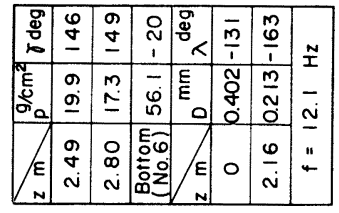

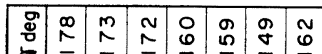

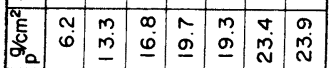

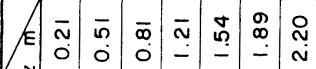

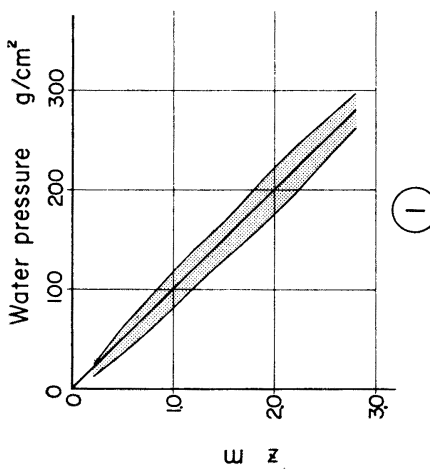

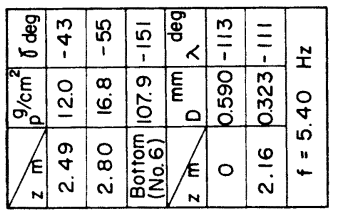

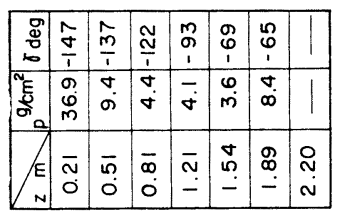
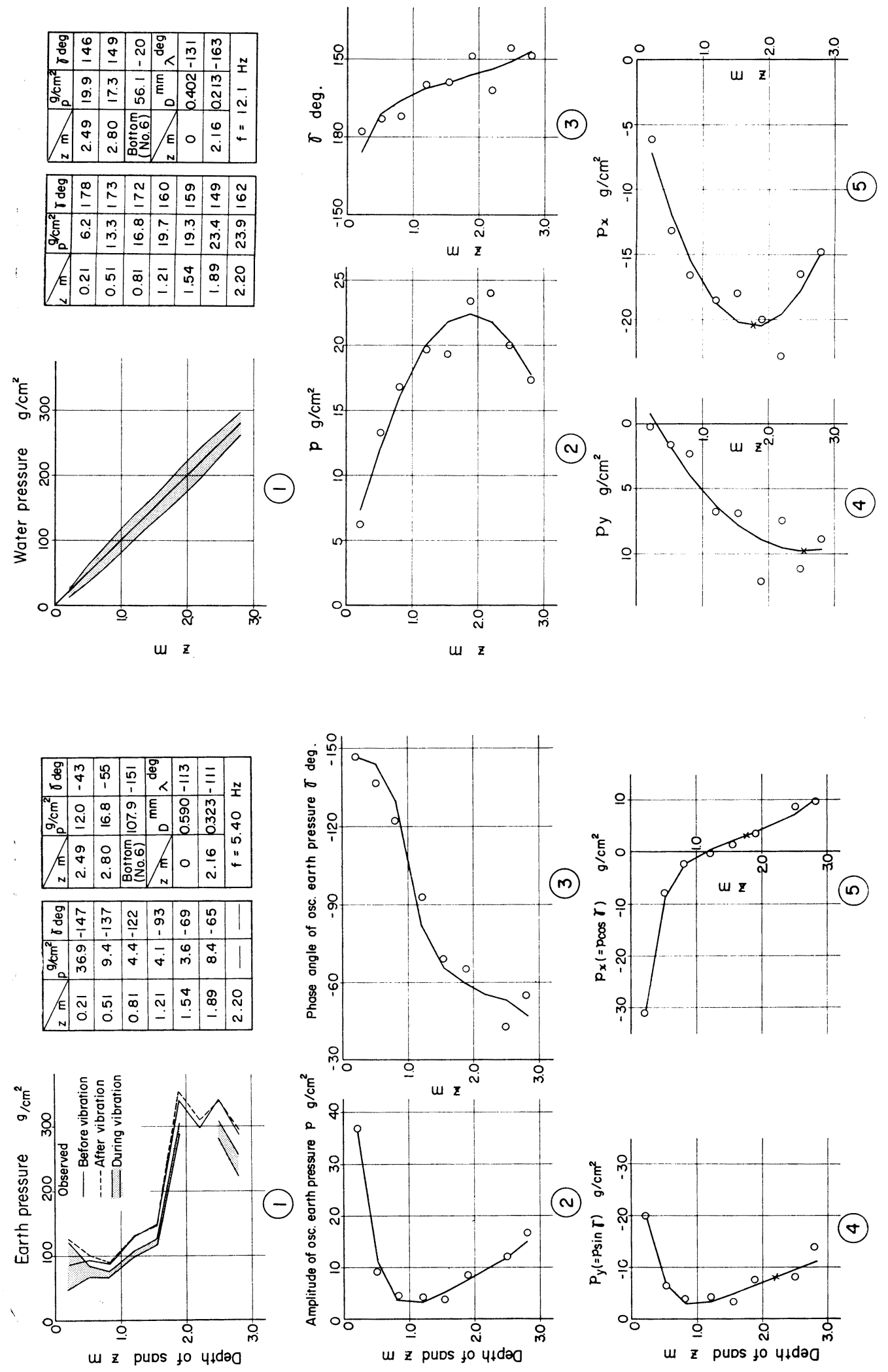

(m)
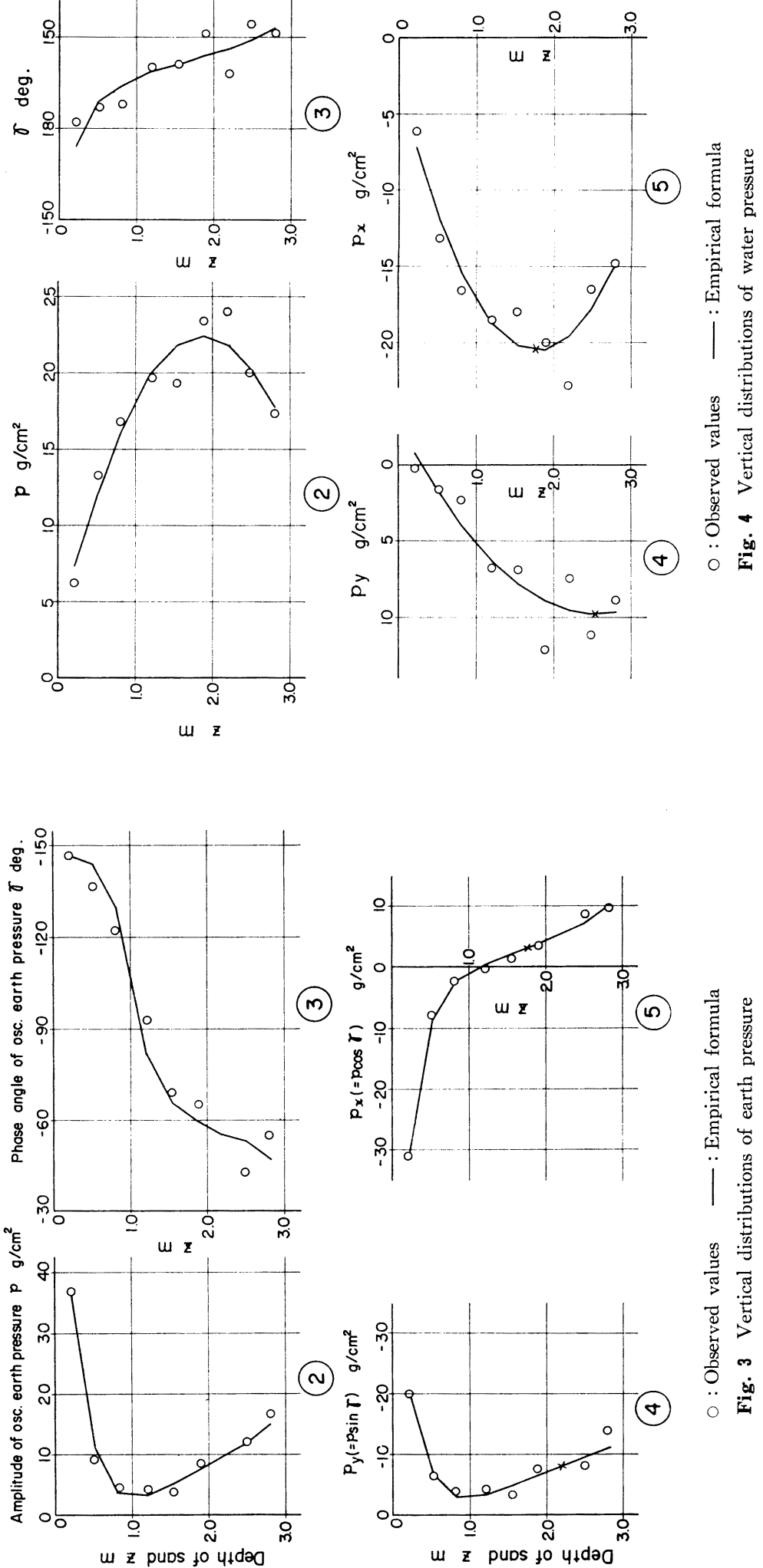
んな具合に変化して行くのか，ということを直視的に， かつすぐそのイメージが頭に浮かふような表現法はない であろうか?。著者はひとつひとつの振動を回転べクト ルで表現しこえれ立体的に配置した表現法を考えた。

いま壁面上のある 1 点に作用する振動土圧を $p \cos (\omega$ $\boldsymbol{t}+\boldsymbol{\gamma}$ )で表わすと

$$
\begin{aligned}
p \cos (\omega t+\gamma) & =p \cos \gamma \cdot \cos \omega t-p \sin \gamma \cdot \sin \omega t \\
& =p_{x} \cos \omega t-p_{y} \sin \omega t
\end{aligned}
$$

ここで,

$$
\left.\begin{array}{l}
p_{x}=p \cos \gamma \\
p_{y}=p \sin \gamma
\end{array}\right\}
$$

であり，これは力のベクトル $p$ が位相角 $r$ を持って， 角速度 $\omega$ で回転している回転べクトルで表わされるこ とは衆知のと拈りである。ここで $\omega t=0$ の瞬閒を考え ると Fig. 5 のようになり（ベクトルの回転方向は $x$ 軸 の正方向が $y$ 軸の正方向と一致する方向にとる), $p_{x} お$ よび $p$ 、はベクトルの絶対值 (振幅) $p$ の， $x$ 拈よび $y$ 軸上への投影となる。 $p$ と $r$ は深さ (測定点) $z$ の関 数であり, Fig. 5 の $p r$ を, 各実測值に㯰きかえ つつ $z$ 方向へ配置して行くと Fig. 6 のようになる。 の先端を結んでできる曲線を $L_{p}, L_{p}$ の $x z$ 平面への

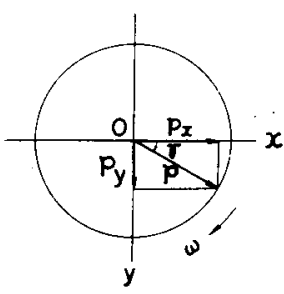

Fig. 5 Rotating vector

投影曲線を ${ }_{x} L_{p}, y z$ 平面一の投 影曲線を ${ }_{y} L_{p}$ で表わすことに する。 $z$ 軸を回転軸として $L_{p}$ が角速度 $\omega$ で回転するとき， ${ }_{x} L_{p}$ は時々刻々その形を変えて 行くが, このときの ${ }_{x} L_{p}$ の横 座標の変化は，まさにPhoto 3

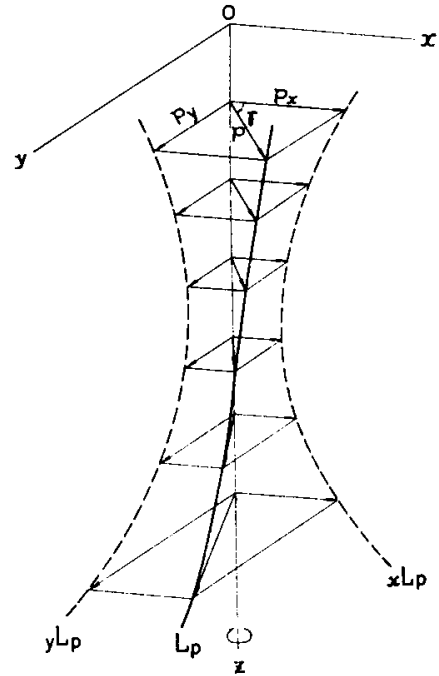

Fig. 6 Representation of oscillating earth pressure employing rotating vectors

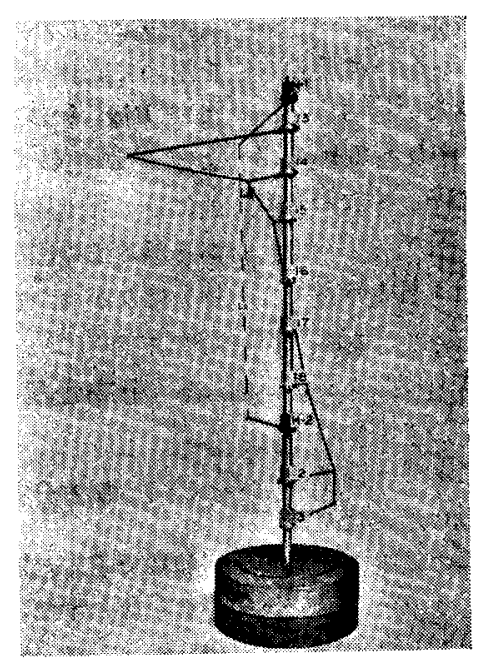

Photo 4 Representation of oscillating earth pressure employing rotating vectors Data No. I -2-5.40, shown in Photo 3
のである。 $L_{p}$ は一般的に空閒曲線であり，これが回転 軸（ $z$ 軸）に剛結されて回転するときそその投影曲線が 壁体の各点に作用する土压を表わすのである。したがっ て空閒曲線 $L_{p}$ を定めることができれば，振動土圧の性 質をあます所なく知りえたことになる。

さきに例示した I-2-5.40の実験結果をこの方法で表 示したのが Photo 4 で， $\omega t=0$ の位置のものである。 また写真中の白黒の線 $L_{D}$ は, 壁体の変位を同様の方法 で表わしたものである。いま Fig. 6 において直線 $o z$ に沿って切断し， $z$ 軸を中心にして $y z$ 拉よび $x z$ 平面 を左右に開くと, $z$ 軸の左側に曲線 ${ }_{y} L_{p}$, 右側に ${ }_{x} L_{p}$ がえがかれた 2 枚のデータをえる。これがさきにかかげ た Fig.3の (4)括よび(5)の意味である。すなわち Fig. 3 の (4) は曲線 $L_{p}$ の $y z$ 平面一の投影曲線 $y L_{p}$ を, (5) は同じく ${ }_{x} L_{p}$ を表わしている。

Photo 5 に, Fig. 4 としてかがけた II-5-12.1の実 験結果を表示したものを示す。前揭のものとはべクトル の縮尺率は違うが,一見して非常に異なっている様子が 良くわかると思う。

以上述べたように空間曲線 $L_{p}$ を定めることが当面の 目標となる。

\section{4. 振動土圧の分布形状の決定一実験式化}

\section{（1） $x z, y z$ 平面への投影曲線を放物線で表わした} 場合

壁体の背後および底面の媒体が Voigt 体であると仮 定して壁体の運動方程式をたてこれを解いた結果から 
背後に作用する振動土圧を求好ると， $L_{p}$ は空間直線 と なる。しかし実測データはこのように簡単な直線形式で は表わしえない。さきに示した Photo 5 (Fig.4) は, 裹込めの砂の代りに水を満たし, 壁頂起振機で加振し て，壁に作用する動水圧を測定した結果を表わしたもの であるが，II-5 の実験結果を立体表示したものを観察 すると, ${ }_{x} L_{p},{ }_{y} L_{p}$ ともに放物線にきわめて近い形をし ている。そこで $x z$ および $y z$ 平面への投影曲線を $\mathrm{Eq}$.

（2）のように放物線で表わした。

$$
\left.\begin{array}{l}
p_{x}=C_{x}\left(z-z_{x}\right)^{2}+\bar{p}_{x} \\
p_{y}=C_{y}\left(z-z_{y}\right)^{2}+\bar{p}_{y}
\end{array}\right\} .
$$

ここで $C_{x}, C_{y}$ は放物線の係数, $z_{x}, z_{y}$ および $\bar{p}_{x}, \bar{p}_{y}$ は各投影面における放物線の頂点の縌および横座標であ る。いま II-5 の実験結果を立体表示し，これを回転し ながらその投影を観察すると，ほぼ直線になる位置が存 在する。そこで Eq. (2) の座標を $z$ 軸のまわりに $\theta^{\prime}=$ $\tan ^{-1}\left\{-\left(C_{x} / C_{y}\right)\right\}$ 回転すれば, $x z$ 平面への投影が直線 になることがわかる。このことは Eq.（2）で示される 曲線は $x z$ 平面に垂直で, この直線を含む平面内にある わけで，本質的に平面曲線であることがわかる。 $p-z$ 曲 線拉よび $\gamma-z$ 曲線は Eq.(1) から次式で与えられる。

$$
\left.\begin{array}{l}
p=\sqrt{p_{x}^{2}+p_{y}^{2}} \\
\gamma=\tan ^{-1} \frac{p_{y}}{p_{x}}
\end{array}\right\}
$$

この場合 $z_{x}=z_{y}$ ならば, 両曲線ともその点を中心にし て上下対称の形を持つことは簡単にわかる。

\section{（2）さらに高次にした場合}

前節で述べた II-5 の実験を除いたものの，(4)および (5)を詳細に調べた結果次のことが明らかとなった。

i）四に表われている分布曲線上か，あるいはその 延長上に曲線の対称点を求めることができる。

ii）この対称点を中心にして, 程度の差はあるがほ とんどすべてのものは奇関数の形をしている。すなわち $z$ の奇数べキの項を含んでいる。

iii）曲線の対称点付近における接線が, $z$ 軸と平行で ないものがほとんどである。

実測データについての以上の性質をふまえて, 実測值 を表現する実験式はさらに，A） $x z$ おおよび $y z$ 平面の曲 線は同じ形の式で表わす。B）実験式はなるべく簡単な ものとする。C) 部分的に 2 次放物線に近い形を含んだ 式とする。などのことを考慮して種々検討の結果, 次式 が最も適したものであるという結論に達した。すなわち，

$$
\left.\begin{array}{l}
p_{x}=A_{x}\left(z-z_{x}\right)^{n}+B_{x}\left(z-z_{x}\right)+\bar{p}_{x} \\
p_{y}=A_{y}\left(z-z_{y}\right)^{n}+B_{y}\left(z-z_{y}\right)+\bar{p}_{y}
\end{array}\right\}
$$

ここで $A_{x}, A_{y}$ は高次放物線の倸数, $B_{x}, B_{y}$ は曲線の 対称点に㧍ける接線勾配, $z_{x}, z_{y}$ および $\bar{p}_{x}, \bar{p}_{y}$ は曲線

の対称点の縦㧍よび横座標 を表わし， $n=3,5,7$ とす る。第 1 式の概形を Fig. 7 に示す。四からも明らか なように $B_{x}>0$ のときは 極值を持たず, $B_{x}<0$ の ときは 2 つの極值を持つ。 Eq. (4) で表わされる空間 曲線は,もし $z_{x}=z_{y}$ という 条件があれば，平面曲線を

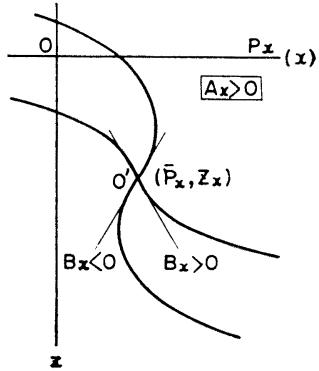

Fig. 7 Schematic diagram of $p_{x}$ in Eq. (4) 表わすことは前節と同様にして証明することができる。

\section{（3）係数の決定}

Eq. (4) に含まれる $A_{x}, B_{x}, \bar{p}_{x}, z_{x}$ などの值は，最 小自乗法と逐次近似法を用いて，その最確值を求めた。 Eq. (2) についても同じである。係数の最確值が求まる と, この值を用いて $z$ を所定の值 (土圧計の位置) にか えて Eq. (4) または Eq. (2) から $p_{x}$ と $p_{y}$ を計算し， さらに Eq. (3) を用いて $p$ と $r$ を求める。 $p_{x}, p_{y}, p$, $\gamma$ を求めるとき, $z$ の各点における残差の自乗和を計算 しておく。Eq. (2) を適用するのは II-5 の実験のみで 他は Eq. (4) を用いるのであるが，このときは $n=3$ ， 5,7 の 3 通りについて 計算し，残差の自乗和 が最小となる $n$ の值を 選ぶ。このようにして 求めた $n$ の值を Table 2 に示す。 $A_{x}, B_{x}$ な

\begin{tabular}{|c|c|c|}
\hline $\begin{array}{l}\begin{array}{r}\text { Source of } \\
\text { vibration }\end{array} \\
\text { Conditions } \\
\text { of backfilling }\end{array}$ & I & II \\
\hline 1 & 3 & 7 \\
\hline 2 & 7 & 7 \\
\hline 3 & 3 & 7 \\
\hline 4 & 3 & 7 \\
\hline 5 & 3 & $2[\mathrm{Eq} .(2)]$ \\
\hline
\end{tabular}
どの值と $n$ の值が求ま ったので，これらの值

Table 2 Values of $n$ を用いて計算した $p_{x}, p_{y}, p, r$ の值を前掲 Fig. 3 お よび Fig. 4 の (5), (4), (2), (3) に実線で示した。(5) お

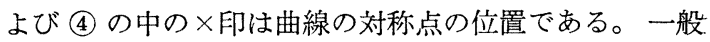
的にいって土圧実験は実測值のばらつきが大きいもので あるが，この図の実測值（O印）と実験式による值（実 線）はなかなか良い一致を示しているといえよう。

\section{5. 分布土圧の積分}

\section{（1） 側方分布土圧の積分}

前章で重力式擁壁の背後に作用する振動土圧の分布を 決定した。すなわち，Eq. (2) あるいは Eq. (4) と Eq. (3) によって, 背後の各点に作用する振動土圧の振幅と 位相角をあます所なく知ることができる。壁面上の任意 の 1 点に作用する振動土圧は，

$$
\boldsymbol{p}=p \cos (\omega t+r)=p_{x} \cos \omega t-p_{y} \sin \omega t \cdots(5)
$$


で表わされている。いま側方振動土圧の合力を $\boldsymbol{P}$, 壁体 の重心に関する合モーメントを $\boldsymbol{M}$ として，これを次の ように置く。

$$
\begin{aligned}
& \boldsymbol{P}=P \cos \left(\omega t+\Theta_{P}\right)=P_{x} \cos \omega t-P_{y} \sin \omega t \\
& \left.\left.\begin{array}{l}
P_{x}=P \cos \theta_{P} \\
P_{y}=P \sin \theta_{P}
\end{array}\right\} \text { 加 } \begin{array}{l}
P=\sqrt{P_{x}^{2}+P_{y}^{2}} \\
\theta_{P}=\tan ^{-1} \frac{P_{y}}{P_{x}}
\end{array}\right\} \cdots(7
\end{aligned}
$$

同様にして

$$
\boldsymbol{M}=M \cos \left(\omega t+\theta_{M}\right)=M_{x} \cos \omega t-M_{y} \sin \omega t
$$

$$
\left.\left.\begin{array}{l}
M_{x}=M \cos \Theta_{M} \\
M_{y}=M \sin \Theta_{M}
\end{array}\right\} \text { 加 } \begin{array}{l}
M=\sqrt{M_{x}{ }^{2}+M_{y}{ }^{2}} \\
\Theta_{M}=\tan ^{-1} \frac{M_{y}}{M_{x}}
\end{array}\right\}
$$

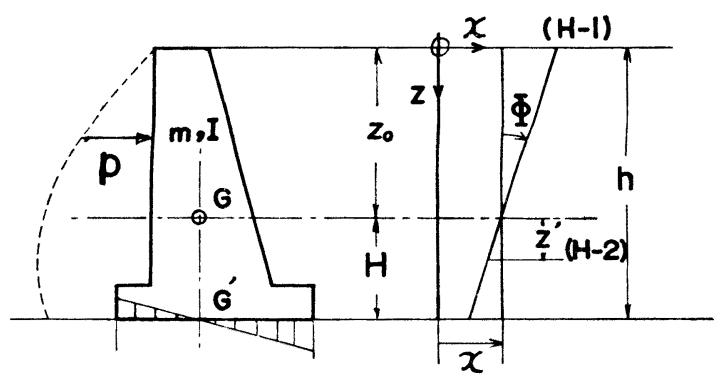

$l:$ length of the wall

Fig. 8 Simbols in relation to the model wall いっぽう, 土圧分布を 2 次元分布と仮定すると, $\boldsymbol{P}$ は Eq.（5）を積分して（Fig. 8 参照）

$$
\begin{aligned}
\boldsymbol{P} & =l \int_{0}^{h}\left(p_{x} \cos \omega t-p_{y} \sin \omega t\right) d z \\
& =\cos \omega t \cdot l \int_{0}^{h} p_{x} d z-\sin \omega t \cdot l \int_{0}^{h} p_{y} d z
\end{aligned}
$$

$\mathrm{Eq} \cdot$ (10) を Eq. (6) と等置して

$$
P_{x}=l \int_{0}^{h} p_{x} d z, P_{y}=l \int_{0}^{h} p_{y} d z \cdots
$$

をえる。また土圧の合モーメントも同様 に,

$$
\begin{aligned}
\boldsymbol{M} & =l \int_{0}^{h}\left(z_{0}-z\right)\left(p_{x} \cos \omega t\right. \\
& \left.-p_{y} \sin \omega t\right) d z=\cos \omega t \\
& \cdot l \int_{0}^{h}\left(z_{0}-z\right) p_{x} d z-\sin \omega t \\
& \cdot l \int_{0}^{h}\left(z_{0}-z\right) p_{y} d z \cdots \cdots \cdots \cdot(12)
\end{aligned}
$$

Eq. (12) を Eq. (8) と等置して

$$
\left.\begin{array}{l}
M_{x}=l \int_{0}^{h}\left(z_{0}-z\right) p_{x} d z \\
M_{y}=l \int_{0}^{h}\left(z_{0}-z\right) p_{y} d z
\end{array}\right\}
$$

をえる。

Eq. (11) と Eq. (13) に, Eq. (2) あ るいは Eq. (4) を代入して積分を実行 し，この結果を Eq. (7) と Eq. (9) に代 大すると合力の振幅と位相角, および合 モーメントの振幅と位相角を求めること ができる。

I群の実験について，以上の計算結果 を図示すると Fig.9 のようになる。こ の図では計算結果を滑らかな曲線に引き なおして示してあり，I-4 の実験は異 なった振動数の実験が 3 つかないので ここでは省略した。I-1 の実験は他よ り実測点のばらつきが大きいが，これは 裏込め投入後初めての振動実験であるた め，振動によって裏込めが“落らつく” 過程の現象ではないかと考えている。そ

Fig. 9 Frequency responses of resultant forces and resultant moments of lateral oscillating earth pressure 
の他のものはこの図の曲線によくのっている。一見して $\Theta_{M}$ の曲線が異常であるが，I-2 および I-3 の曲線 の，振動数の低い方ではやや疑問がある。

\section{（2）底面に作用する振動土圧}

振動中における力のつり合いを考える第 1 の準備とし て, 振動中の底面反力の実測值を調べよう。Fig. 2 に示 したように底面には 3 個の土圧計が取り付けてあるが, このうち, 中央の No. 5 はほとんど機能を失っており, Heel 側の No. 4 も完全ではない。壁体の構造上, あま り沢山の土圧計を底面に取り付けることもできず，いま の場合, 1 個の土圧計が故障すると, 底面反力の分布形 状を正確に決定するのが困難になる。またたとえ土圧計 が完全であっても，実測值のばらつきは側方土圧より大 きく, 実測值から底面反力の分布形状を決定するのは容 易なことではない。

土圧計 No. 4 の記録は完全なものではないが，裏込 めのない場合の実測值を調べると，i）振動数の低い方 では振幅は Heel 側と Toe 側で, Fig. 8 の $G^{\prime}$ 点を 通る直線分布になるが, 位相角は両者で必ずしも逆相に なっていない。ii）振動数の高い方では振幅は直線分布
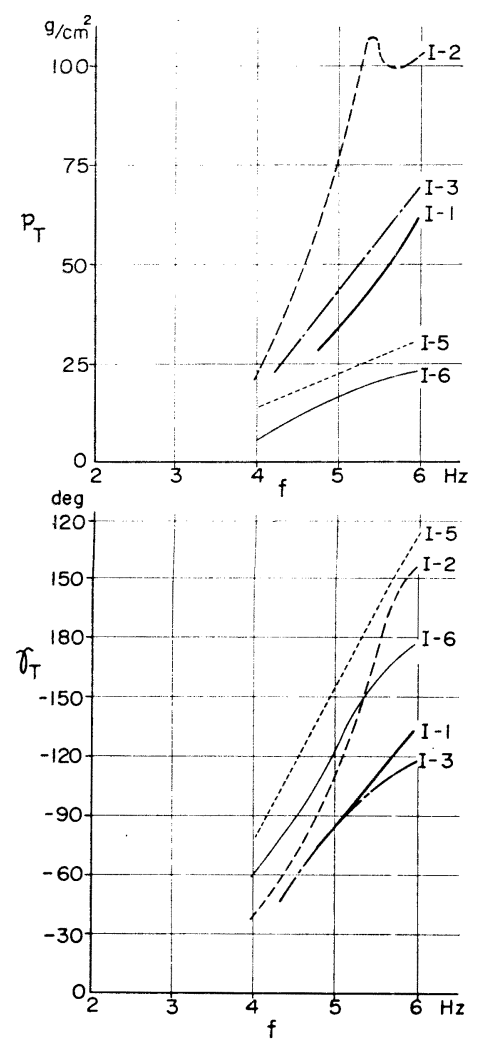

Fig. 10 Frequency responses of vertical oscillating earth pressure observed by the cell No. 6
になっていないが，位相角は完全に逆相になっている。 壁体背後に側方土圧が作用している場合の 底面反力 は, Heel 側の記録で解析に耐えるものが少なく， 、き おい, Toe 側の実測值にたよらざるをえない。Fig. 10 に側方土圧が作用したときの土圧計 No. 6 の実測值を 示す。今後, Toe 側の底面反力の実測值を $\boldsymbol{p}_{T}=p_{T} \cos$ $\left(\omega t+\gamma_{T}\right)$ で表わすこととする。

\section{6. カのつり合い}

\section{（1）変位の分解}

振動中における力のつり合いを考える第 2 の準備とし て, 実測によってえられた壁体の変位を並進成分 $x$ と回 転成分 であるが,この実験に用いた振動測定器の倍率では, 上 下動は観測にかからなかったので以下ではこれを無視す る。

Fig. 8 に示したように, 壁頂 (H-1 の位置)におけ る壁体の水平変位振幅を $D_{1}$, 位相角を $\lambda_{1}$ とし, $\mathrm{H}-2$ の 位置に㧍けるそれを $D_{2}, \lambda_{2}$ とすると

$$
\left.\begin{array}{l}
x+z_{0} \Phi=D_{1} \cos \left(\omega t+\lambda_{1}\right) \\
x-z^{\prime} \Phi=D_{2} \cos \left(\omega t+\lambda_{2}\right)
\end{array}\right\}
$$

となる。この式に $x=a \cos (\omega t+\alpha), \Phi=\varphi \cos (\omega t+\beta)$ を代入し， $a, \alpha, \varphi, \beta$ を求めればよい。このようにして 求めた結果を Fig. 11 に示す。I-2 の実験は $a, \varphi$ と もに $5.3 \mathrm{~Hz}$ でピークを持つが，これは裹込め上に置か れた載荷重の共振を示している。

\section{（2）力と変位に関する定性的考察}

カのつり合いを論ずる前に, ここで Fig. 9, Fig. 10, Fig. 11 を包括的に眺めてえられる, 力と変位について の定性的な特性を列記してみる。

1）並進変位の振幅 $a$ は, 水平合力 $P$ の有無, 大小 にかかわらず 1 本の振動数特性で表わしらるとみなされ る。I-5 を除いた位相角も力と変位とでは比較的近い 值をとる。

2) 回転変位の振幅 $\varphi$ は, 合モーメント $M$ の有無, 大小，および Toe 側の底面反力 $p_{T}$ の大小にかかわら ず 1 本の振動数特性で表わしうるとみなされる。しかし I-2 および I-3 のように $\varphi$ にピークがあっても，そ れに対応する $M$ の位置にピークがないもの，あるいは その逆の場合などが含まれている。位相角は $\beta$ と $\gamma_{T}$ は 似た傾向を示すが， $\theta_{M}$ のみは他と非常に異なった傾向 を示している。

3) 以上の 2 点を要約すると, 外力およびそのモーメ ント $P, p_{T}, M$ は実験の種類 (I - $1, I-2, I-3$ など) によって極端に異なった值をとるが, それらが原因で起 

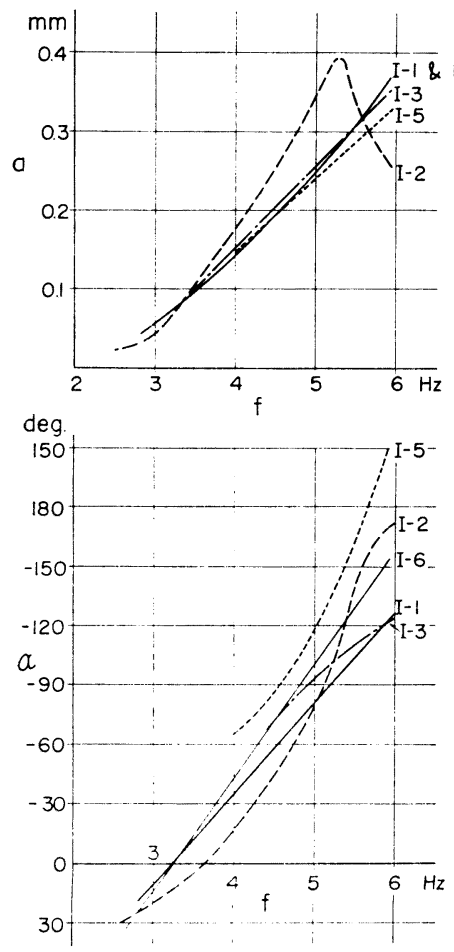
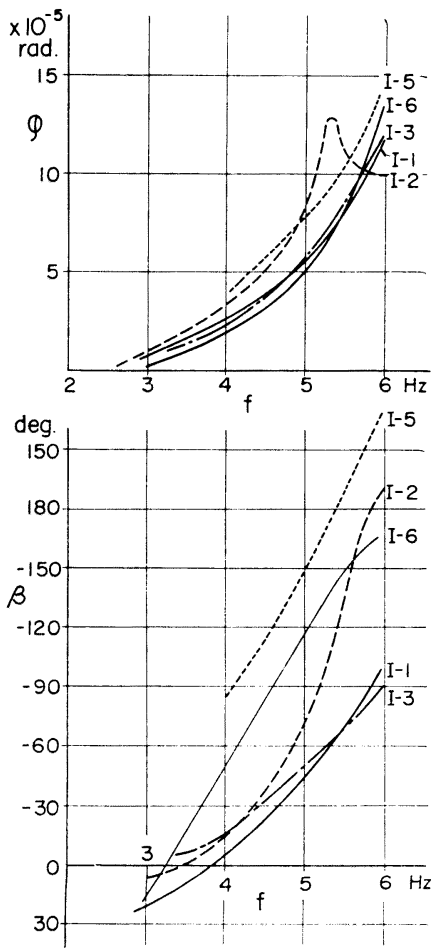

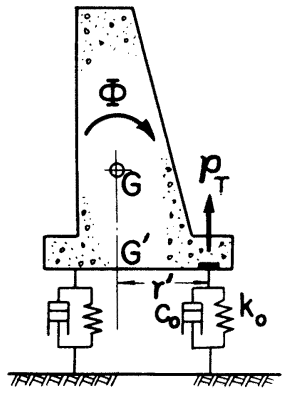

Fig. 12 Simple model of foundation of the wall

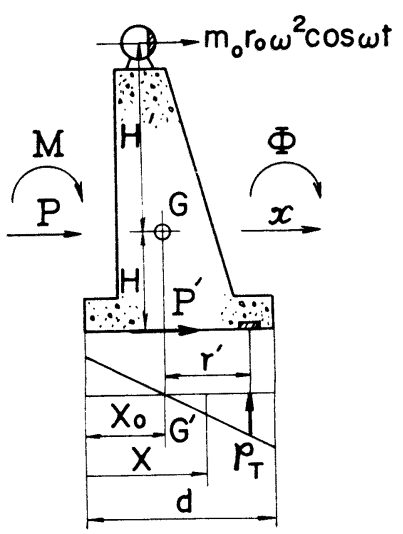

Fig. 13 Equilibrium of forces and moments
こる変位 $a, \varphi$ は常に同じ值を示し, 1 本の振動数特性 で表わされ, かつ $a, \varphi$ ともに裏込めがない場合のもの （I-6）で代表される。すなわち，振幅だけを見ている と, あたかも力と変位の間には直接的な関係がないかの ように見える。

4）並進および回転変位の位相角 $\alpha$ と $\beta$ は, 互いに平 行移動すれば大体一致する。全体として $\alpha, \beta, \Theta_{P}, r_{T}$ が同じ傾向で， $\theta_{M}$ のみが著しく異なった傾向を示す。 ただし I-1 の実験のみは， $\theta_{P}$ と $\theta_{M}$ は振動数のいか んにかかわらずほぼ正確に逆相関係である。

5）裹込め部分に水を満たした実験（I-5）では，位 相遅れが一番大きく，この場合を除くと， $\alpha, \beta, r_{T}$ とも にI-6 の実験が最も遅れが大きい。すなわち, 並進お よび回転変位, Toe 側の底面反力の位相は, 裹込めが ない場合が一番遅れ，裏込めがある場合の方が遅れが小 さい。

6）いま簡単な底面基礎の力学モデルとして Fig. 12 を考え, Toe 側の底面反力 $\boldsymbol{p}_{T}$ を求める。 $\boldsymbol{p}_{T}$ は上向 きを正とすると

$$
\boldsymbol{p}_{T}=p_{T} \cos \left(\omega t+r_{T}\right)=r^{\prime}\left(k_{0} \Phi+C_{0} \dot{\Phi}\right)
$$

となる。ここで $r^{\prime}$ は土圧計 No. 6 と壁体の重心との水 平距離, $k_{0}, C_{0}$ は底面の分布ばね係数, および分布減衰 係数である。この式から明らかなように， $r_{T}$ は $Ф$ の位
相角 $\beta$ よりも必然的に進まねばならない。しかるに実測 值では $\gamma_{T}$ が $\beta$ より逆に遅れている。両者の位相角は, この振動数の範囲では平行移動すれば一致し, その量は 実験の種類によって異なるが， $0^{\circ} \sim 40^{\circ}$ の範囲である。

\section{(3) カのつり合い}

剛体としての壁体に作用する力とモーメント，および 壁体の変位が明らかになったので，振動中にこれらがど のようにして運動方程式を満足するかを調べよう。すで に5.(2)で述べたように，底面に作用する力で解析に耐 えるのは Toe 側のデータのみであり, Heel 側の力は これから推定せざるをえない。振動中に底面反力を生じ させる原因は，壁体の回転変位と上下動であると考えら れるが，実験で、上下動は観測されなかった。このことを 考慮して底面反力の分布を Fig. 13 に示すように, Toe 側の実測值 $p_{T}$ と, 壁重心直下の $G^{\prime}$ 点を結ぶ直線分布 とし, Toe 側と Heel 側とでは逆位相であると仮定す る。底面分布土圧によって生じる壁体の重心に関するモ ーメントを $M_{b}$ とすると， $M_{b}$ は Fig. 13 を参照して 次のように求められる。

$$
\boldsymbol{M}_{b}=-l \int_{0}^{d} \frac{\boldsymbol{p}_{T}}{r^{\prime}}\left(X-X_{0}\right)^{2} d X=-\frac{J_{3}}{r^{\prime}} \boldsymbol{p}_{T}
$$

ここで $J_{3}$ は壁底面の 2 次モーメントである。 
壁体に作用する力とモーメント，および壁体の変位は Fig. 13 に示したようになり, 壁体の運動方程式は次の ように表わされる。

$$
\left.\begin{array}{l}
m \ddot{x}=\boldsymbol{P}+\boldsymbol{P}^{\prime}+m_{0} r_{0} \omega^{2} \cos \omega t \\
I \ddot{\Phi}=\boldsymbol{M}-H \boldsymbol{P}^{\prime}-\frac{J_{3}}{r^{\prime}} \boldsymbol{p}_{T}+H^{\prime} m_{0} r_{0} \omega^{2} \cos \omega t
\end{array}\right\}
$$

ここで $\boldsymbol{P}^{\prime}$ は壁体の底面に作用する水平力の合力を表わ す。また $m_{0} r_{0}$ は壁頂起振機の不平衡モーメント， $H^{\prime}$ は 壁頂起振機の回転軸と壁体の重心との鉛直距離である。 Eq. (15) でI 群の実験では $m_{0}=0$ と置く。

壁体の底面に作用する水平方向の分布力は実測するこ とがほとんど不可能である。したがって実験によって直 接 $\boldsymbol{P}^{\prime}$ を求めることができないので，Eq. (15) の第 1 式 から逆算せざるをえない。 $\boldsymbol{P}^{\prime}$ を求めてこの值を $\mathrm{Eq}$.

（15）の第 2 式に代入して左右辺がベクトルとして一致 すれば，すべてり実測值が運動方程式を满足したことに なる。しかしこれは成功しなかった。そこで $\boldsymbol{p}_{T}$ の代り に $\boldsymbol{p}_{T^{\prime}}\left\{=p_{T^{\prime}} \cos \left(\omega t+r T^{\prime}\right)\right\}$ と扔きかえて，運動方程 式を満足する $\boldsymbol{p}_{T^{\prime}}$ を逆算し $\boldsymbol{p}_{T}$ と $\boldsymbol{p}_{T^{\prime}}$ を比較して見 ることとした。すなわち運動方程式は

$$
\left.\begin{array}{l}
m \ddot{x}=\boldsymbol{P}+\boldsymbol{P}^{\prime}+m_{0} r_{0} \omega^{2} \cos \omega t \\
I \ddot{\phi}=\boldsymbol{M}-H \boldsymbol{P}^{\prime}-\frac{J_{3}}{r^{\prime}} \boldsymbol{p}_{T^{\prime}}+H^{\prime} m_{0} r_{0} \omega^{2} \cos \omega t
\end{array}\right\}
$$

と書き改められる。Eq. (16) から求めた $p_{T} T^{\prime}$ と $\gamma T^{\prime}$ を Fig. 14 に示す。Fig. 14 と Fig. 10 を比較してみる と次に列記する事柄に気付く。ここで Fig. 14 の縦軸 は Fig. 10 の半分に縮めてあることに注意されたい。

1）振動数の低い所では実測值がないので両者を比較 することはできないが，振幅においても，位相角におい ても両者の間に強い近親性のあることが認められる。 $\boldsymbol{p}_{T}{ }^{\prime}$ の計算には, $x, \Phi, \boldsymbol{p}$ の実測值に伴う誤差とばらつ きが含まれていることを考えると，この計算結果のばら つきは非常に小さく, 良好な結果であるといえる。

2) まず振幅についてであるが， $p_{T}$ と $p_{T}{ }^{\prime}$ の傾向は 良く一致し, 振動数に対する分布形状も丽者で大体一致 する。 $p_{T^{\prime}} / p_{T}=\nu$ は大半のものは $1.6 \sim 2.7$ の範囲内に あり, 全部の平均は 2.1 である。

3) 両位相角の差 $\gamma T^{\prime}-\gamma T=\varepsilon$ は， I -7 および I -6 では，振動数のいかんにかかわらず約 $20^{\circ}$ であり，他は $10^{\circ}$ 以下であって誤差の範囲で 両者は一致するものとみ なされる。ただ I-1 と I-2 で $4 \mathrm{~Hz}$ 以下の $\gamma_{T} T^{\prime}$ の值 が急激に変化する。この点に対応する実測值がないので 比べられないが, $\boldsymbol{M}$ の位相角 (Fig. 9 参照) がきいて いるようで, 前述のようにやや疑問が残る。 $\gamma_{T}$ と $\gamma_{T}{ }^{\prime}$ を全般的に比べると， $r T^{\prime}$ の方が進んでいる場合がほと
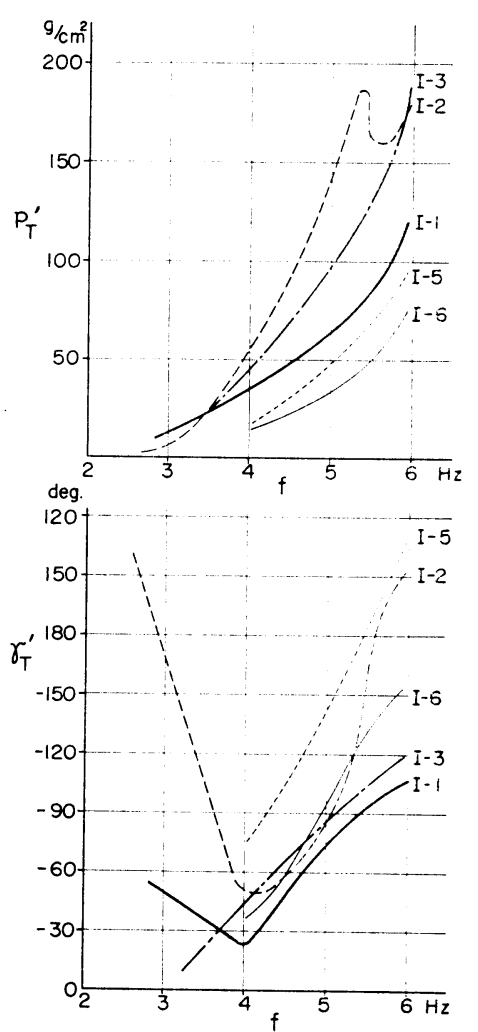

Fig. 14 Frequency responses of vertical oscillating earth pressure at the position of the cell No. 6, calculated by Eq. (16)

んどである。また壁体の回転変位 Dの位相角 $\beta$ (Fig. 11 参照) とここでえた力の位相角 $r T^{\prime}$ を比べると， I -6 の場合だけ $\gamma_{T}{ }^{\prime}$ が $\beta$ より進んでいて, 他は一致す るか, あるいは $20^{\circ} \sim 30^{\circ}$ 程度 $r_{T}{ }^{\prime}$ が遅れている。ここ でも 6.(2)，6）で述べた疑問がなお残っている。

以上は I 群の実験についてであるが，I群の実験につ いては

4）Ｉ群の場合とくらべて点のばらつきがやや大き $く, \nu, \varepsilon$ ともに振動数に対して平坦になる場合は少な く, 一般的にゆるやかな直線変化をする。その絶対值も I 群の場合より大きく, $\nu=2 \sim 4, \varepsilon= \pm 40^{\circ}$ の範囲内に 分布している。

5） II-5 は $\gamma T^{\prime}$ が $\gamma T$ より遅れるが，他はす心゙て $r_{T}{ }^{\prime}$ が進んでいる。 $\gamma_{T^{\prime}}$ と $\beta$ をくらべると，ほとんどのも のは力の位相角の方が進んでいて, この場合は常識的に 理解しやすい形となっている。

本節では運動方程式 Eq.(15) を満足させるためには, 実測值 $\boldsymbol{p}_{T}$ の代りに $\boldsymbol{p}_{T}{ }^{\prime}$ を用い㸚ばならず， $\boldsymbol{p}_{T}{ }^{\prime}$ は $\boldsymbol{p}_{T}$ と強い近親関倸にあることがわかった。しからば $\boldsymbol{p}_{T}{ }^{\prime}$ と $\boldsymbol{p}_{T}$ は力学的にどのような関倸にあるのであろうか？ 次節で両者の相互関係について考えてみよう。 


\section{（4）底面に作用する振動土圧分布の決定}

前節で底面の鉛直分布土圧を積分してそれによるモ一 メントを求めるとき, 暗黙のうちに底面の 2 次元分布 （壁体の長さ $l$ の方向に）を仮定していた。いま土圧計 No. 6 の位置を通り壁体の $l$ 方向の断面を考えると,

Fig. 15 に示すように $p_{T}{ }^{\prime}>p_{T}$ という関係はすべての 実験結果について成立 するから，図示のよう にlの方向に上に凸の 分布曲線を考えれば, 実測值 $p_{T}$ は分布力の

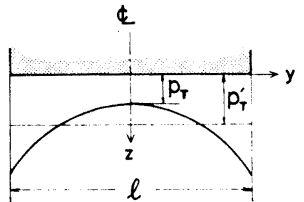

最小値を測っていたこ Fig. 15 Horizontal distribution of との関係が無理なく理 at the longitudinal section passing 解される。すなわち, through the cell No. 6

壁体の長さ方向に 3 次元分布を考え, この分布曲線によ って囲まれる面積が $p_{T^{\prime}}{ }^{\prime} l\left(p_{T^{\prime}}\right.$ は長さ方向の各断面で 異なっている) になるように曲線を定めれば，各断面に おける分布曲線の集りが運動方程式を满足することにな る。実際には振幅と同時に位相角の分布も考慮に入れな ければならない。

Fig. 16 亿示すよう に座標を定め, 壁体の 幅方向の断面における 底面振動土圧の分布を 前節と同様に直線分布 とし，その中央断面に おける分布を

$$
\left(X-X_{0}\right) \frac{p_{T}}{r^{\prime}}
$$

とする。また $y$ 軸方向 の分布形状について は, すでに 4. (1) で論 bution of vertical oscillating earth ビた方法の応用として pressure acting on the bottom 二つの放物筒面の交線 surface

として表わすこととする。いま任意の点における底涌振 動土圧を $\boldsymbol{p}_{b}$ とすると $\boldsymbol{p}_{b}$ は次式で表わされる。

$$
\begin{aligned}
\boldsymbol{p}_{b}= & \left(X-X_{0}\right)\left\{\left(E_{x} y^{2}+N_{x}\right) \cos \omega t\right. \\
& \left.-\left(E_{z} y^{2}+N_{z}\right) \sin \omega t\right\} \cdots \cdots \cdots \cdots
\end{aligned}
$$

この式に含まれる倸数を中央断面における実測值で表 わしてみる。Eq. (17)に に $y=0, X=X_{0}+r^{\prime}$ で $\boldsymbol{p}_{b}=\boldsymbol{p}_{T} \cos$ $\left(\omega t+r_{T}\right)$ という条件を入れると

$$
\left.\begin{array}{l}
N_{x}=\frac{p_{T}}{r^{\prime}} \cos r_{T} \\
N_{z}=\frac{p_{T}}{r^{\prime}} \sin r_{T}
\end{array}\right\}
$$

をえる。底面分布土圧による合モーメント $\boldsymbol{M}_{b}$ は

$$
\begin{aligned}
-\boldsymbol{M}_{b}= & \int_{-l / 2}^{t / 2} \int_{0}^{d}\left(X-X_{0}\right) \boldsymbol{p}_{b} d X d y=J_{3}\left\{\left(\frac{E_{x} l^{2}}{12}+N_{x}\right)\right. \\
& \left.\cdot \cos \omega t-\left(\frac{E_{z} l^{2}}{12}+N_{z}\right) \sin \omega t\right\}
\end{aligned}
$$

これが Eq. (16) を満足させるためには次式が成立しな ければならない。

$$
\begin{gathered}
J_{3}\left\{\left(\frac{E_{x} l^{2}}{12}+N_{x}\right) \cos \omega t-\left(\frac{E_{z} l^{2}}{12}+N_{z}\right) \sin \omega t\right\} \\
\quad=\frac{J_{3}}{r^{\prime}} \boldsymbol{p}_{T^{\prime}}=\frac{J_{3}}{r^{\prime}} \nu p_{T} \cos (\omega t+r T+\varepsilon)
\end{gathered}
$$

この式から

$$
\left.\begin{array}{l}
E_{x}=\frac{12}{l^{2}} \frac{p_{T}}{r^{\prime}}\left\{\nu \cos \left(r_{T}+\varepsilon\right)-\cos r_{T}\right\} \\
E_{z}=\frac{12}{l^{2}} \frac{p_{T}}{r^{\prime}}\left\{\nu \sin \left(r_{T}+\varepsilon\right)-\sin r_{T}\right\}
\end{array}\right\}
$$

をえる。したがって実測值を満足する運動方程式は Eq.

(16) の代りに次式となる。

$$
\begin{aligned}
m \ddot{x}= & \boldsymbol{P}+\boldsymbol{P}^{\prime}+m_{0} r_{0} \omega^{2} \cos \omega t \\
I \ddot{\oplus}=\boldsymbol{M} & -H \boldsymbol{P}^{\prime}-\int_{-l / 2}^{l / 2} \int_{0}^{d}\left(X-X_{0}\right) \boldsymbol{p}_{b} d X d y \\
& +H^{\prime} m_{0} r_{0} \omega^{2} \cos \omega t \\
\boldsymbol{p}_{b}= & \left(X-X_{0}\right)\left\{\left(E_{x} y^{2}+N_{x}\right) \cos \omega t\right. \\
& \left.-\left(E_{z} y^{2}+N_{z}\right) \sin \omega t\right\}
\end{aligned}
$$

ここで $N_{x}, N_{z}$ は Eq. (18) で, $E_{x}, E_{z}$ は Eq. (19) で 与えられる。I 群の実験では $m_{0}=0$ とおく。

以上，底面に作用する振動土圧を 3 次元分布と考える ことによって，実測によってえられた力と変位は運動方 程式 Eq. (20) を満足することを示した。実測した力と 変位が運動方程式を満足するといらことは，これらの実 測值を用いて土圧を受ける重力式擁壁の力学モデルを考 えて良いということを意味し，Eq. (16) または Eq. (20) は力学モデルを考えるときの指標となるものである。

\section{7. 結びとあとがき}

人工地震発生装置を加振源とした実験は, 自然地震に よって起こる現象の本質をそこなわないようにこれを単 純化したものであり，実験に用いられた試験壁体は，現 場で用いられている最小程度の規模のものであるから， 実験の相似則に気を使うことなく，ここにえられた実験 データは現実のありのままの姿を示しているといえよ う。またこの実験は隣接地域にかなりの振動障害を起こ すので，現在の社会情勢のもとでは，もはやこの実験を 再現することがほとんど不可能であることを考え合わせ ると，この実験結果は，まことに貴重なものであると思 う。用いられた測定装置は，その後の急速な技術革新を 経た今日からふり返えってみても，いささかも陳腐性を 感じさせないばかりか，振動土圧計に至っては，まさに 
今日いらディジタル計測の原理そのものであり，この on-off 判別の結果を重ね合わせてアナグロ表示したもの と考えることができる。ここで用いた振動土圧測定装置 に，現在の新しい技術の光をあてて検討すれば，そこに 新しい発展への芽がかくされていることが発見できるで あろう。

実験によってえられた壁体背後に作用する振動土圧を 立体表示法によって表現すれば，ベクトルの振幅と位 相，その作用点と時間的変化を同時に表わすことができ る。このように実験結果を直視的な形で表現すること は，複雑な現象を理解する上で大いに役立つ。またこの 立体表示は土圧に限らず，実測值が正弦変化をする場合 に広く応用されるものである。

実測によってえられた壁体背後に作用する振 動土圧 は，Eq. (4) によってあます所なく表現され，この式は 簡単に積分されて合力と合モーメントが求められる。こ のようにして求めた壁体に作用する力とその変位は，6. （3）および 6.(4)で述べたように考えることによって， 運動方程式を満足させることができ，この運動方程式を 基礎にして，振動中に土圧を受ける壁体の力学モデルへ の道が開かれたのである。また 6.(2) に示した力と変位 の間にある定性的な関係，および Eq. (16) または Eq. (20) は力学モデルを考える上での大切な指標となる。

この報告書の最初に述べたように，“振動土圧に関す る研究” は 2 期に区分され, その第 1 期の研究を総括し て文献 8）にかかげたものにまとめた。しかしその内容 については不満が多く, 当初から書き改めたいと願って いた。幸い，実験を最初から組織的に行なう機会にめぐ まれ，その実験結果を解析するためにも十分な時間が与 えられたので，前報を改訂するつもりで個々の問題に取 り組んだ。しかし結果は，この研究の最終目標である力 学モデルの完成までの道のりが，はるかに遠くてけわし いことを痛感させられたにとどまり，まことに残念であ
るとともに著者の力の無さを恥じるばかりとなってしま った。今後, 本報告を一つの踏み台として, 同学の士が 大いにこの分野を発展させられることを切望するもので ある。

本報告書をとじるに当って，次の方々にお礼申し上げ ねばならない。第 1 には，昭和 28 年に著者がこの研究 にたずさわってから延々 18 年の長い歳月にわたって, 常に行きとどいたご指導と, 暖かい御はげましを賜わっ た 学習院大学学長 近藤正夫先生に心からお礼申し上げ る。第 2 には, 第 2 期にあたる研究の機会を与えられ, 実験結果の解析に十分な時間を与えて頂いた当研究所の 上司の方々に深く感謝の意を捧げる。第 3 には，第 2 期 の実験をともに行ない，実験資料の整理などに協力して 頂いた当研究室山川賢次技官に感謝する。

なお，本報告の詳細は船舶技術研究所報告に登載され る予定であることを付記しておく。

\section{参考 文 献}

1) Kondo M, G. Hasegawa, M. Ichihara, and S. Niwa, : Researches on Earth Pressures, Part I, Report of Transportation Technical Research Institute, No. 15, May, 1955, pp. 1 11

2）市原松平・丹羽 新：人工地震発生装置および地震時土圧 測定装置について, 土木学会論文集, 第 38 号, 昭 31.10 pp. $43 \sim 48$

3）丹羽 新：壁体自身の振動による裹込土圧の実測，土木学 会論文集，第 39 号，昭 31.12 , pp. 58 61

4) 丹羽 新: 振動土圧に関する研究, 運輸技術研究所報告, 8 巻 3 号, 1958 年 9 月, pp. 1 30

5） 丹羽 新：人工地震発生装置による振動土泎の実測, 土木 学会論文集, 第 60 号, 昭 34.1 , pp. 54 59

6）丹羽 新：陰極線オシロスコープによる定常地震動（変 位・速度・加速度)の観測装置, 土木学会誌, 45 巻 6 号, 昭 35.6, pp. 29 34

7) S. Niwa, : An Experimental Study of Oscillating Earth Pressures Acting on A Quay Wall, Proc. of the 2 nd WCEE, Vol. I, July, 1960, pp. 281 296

8）斗羽 新：地震時士圧による擁壁の振動機構について, 私費出版，昭 36.7, pp. 1 215

(1971.4.30 · 受付) 